\title{
Bovine Immunodeficiency Virus
}

National Cancer Institute

\section{Source}

National Cancer Institute. Bovine Immunodeficiency Virus. NCI Thesaurus. Code

C117711.

A lentivirus that is similar to human immunodeficiency virus and that infects cattle. 